\title{
TOPONOMI DESA SE-KECAMATAN SRONO KABUPATEN BANYUWANGI
}

\author{
Devita Sari ${ }^{1}$, Agus Mursidi ${ }^{2}$ \\ Fakultas Keguruan dan Ilmu Pendidikan, Universitas PGRI Banyuwangi ${ }^{1}$ \\ Email: Saridevita2345@gmail.com \\ Email: agusmursidi78@gmail.com
}

\begin{abstract}
ABSTRAK
Toponimi merupakan ilmu atau studi tentang nama - nama geografis Toponimi sendiri mempunyai arti " penamaan unsur - unsur geografis" nama nama pulau, gunung, sungai, bukit, kota, desa. Toponimi juga berpotensi untuk dijadikan sebuah sumber belajar dalam pendidikan, namun dalam pelaksanaannya perlu menggunakan pendekatan antara geografis, sejarah, dan filsafat. Pada pelaksanaannya, Toponimi memiliki banyak komponen dan anggota yang memiliki tugas masing-masing seperti pengelompokan bagian yang ada dalam setiap masingmasing desa, pengelompokan disini berisikan tentang adanya pengelolaan yang ada di setiap desa. Penelitian ini bertujuan (1) menganalisis sejarah desa se-kecamatan Srono Kabupaten Banyuwangi, (II) menganalisis pengelompokan toponimi desa di Kecamatan Srono, dan (III) menganalisis nilai-nilai sejarah yang terkadang di dalam toponimi desa. Penelitian ini merupakan penelitian kualitatif. Dengan teknik yakni: observasi, wawancara, dokumentasi. Hasil penelitian menunjukkan Toponimi desa se- Kecamatan Srono Kabupaten Banyuwangi.
\end{abstract}

Kata kunci : Toponimi, Srono.

\begin{abstract}
ABSTRAK
Toponymy is the science or study of geographical names Toponimi itself means "naming geographical elements" name names of islands, mountains, rivers, hills, cities, villages. Toponymy also has the potential to be used as a learning resource in education, but in practice it is necessary to use an approach between geography, history and philosophy. In practice, Toponimi has many components and members who have their respective tasks such as grouping parts that exist in each village, grouping here contains the existing management in each village. This study aims (1) to analyze the history of villages in the Srono sub-district of Banyuwangi Regency, (II) analyze the village toponymy in Srono District, and (III) analyze the historical values that are sometimes in the village toponymy. This research is a qualitative research. With techniques namely: observation, interviews, documentation. The results of the study showed that the village Toponimi in Srono District, Banyuwangi Regency.
\end{abstract}

Keywords: Toponimi, villages, Srono. 


\section{Pendahuluan}

Banyuwangi memiliki luas wilayah $5.782,50 \mathrm{~km}^{2}$, pada tahun 2017 terdiri atas 25 Kecamatan, 28 Kelurahan dan 189 desa, 87 Lingkungan dan 751 Dusun, 2.839 Rukun Warga (RW) dan 10.569 Rukun Tetangga (RT). Tahun 2017 penduduk Kabupaten Banyuwangi sebanyak 1.692.324 jiwa, terdiri dari 841.899 jiwa perempuan dan 850.425 jiwa laki-laki.Penamaan tempat merupakan bagian budaya manusia yang tidak dapat dipisahkan.Srono adalah sebuah Kecamatan di Kabupaten Banyuwangi, Provinsi Jawa Timur Indonesia yang memiliki 10 desa. Penelitian ini menarika karena toponimi dari 10 desa yang ada di Kecamtan Srono belum ada yang meneliti. Sedangkan generasi penerus dari desa tempat mereka tinggal tidak mengenal asal usul desa yang mereka tinggali karena berputarnya keadaan yang semakin hari semakin modern menimbulkan ke tidak peduliannya akan silsilah dan sejarah desa.

asal usul desa ini merupakan salah satu pembelajaran bagi pemuda pemudi supanya lebih banyak lagi mengenal tentang sejarah desa yang mereka tingal. Kesan terhadap suatu tempat bagi manusia begitu mendalam sehingga penamaan suatu tempat seringkali memiliki nilai-nilai yang perludilestarikan keberadaannya. Dalam pemberian nama suatu tempat atau wilayah, tak jarang terdapat kesamaan antara nama dua daerah. Hal ini akan menimbulkan kerancuan terutama di tingkat pemerintah. Nama suatu tempat biasanya dilatar belakangi oleh asal-usul tempat tersebut yang biasa disebut legenda ataupun dari fenomena yang terjadi di tempat tersebut. Tidak dapat dipungkiri, penamaan tempat yang sama di daerah satu dan lainnya masih sering terjadi di Indonesia. Dalam hal ini, survei topinimi perlu dilakukan guna menghindari hal tersebut. Toponimi sangat erat kaitannya dengan informasi geospasial.

Toponimi suatu tempat merupakan sebagai hasil budaya, baik budaya secarahistoris dan simbolis. Menurut Liliwer (2014:7-8). "budaya secara historis adalah bawaan sosial atau tradisi yang melewati generasi yang lalu ke generasi masadepan" dan budaya secara simbolis adalah"pendasaran makna yang ditetapkan bersama oleh masyarakat".

Toponimi tidak dapat lepas dari aspek kajian linguistik, antropologi, geografi, sejarah, dan kebudayaan.Dengan demikian toponimi merupakan sebuah ilmu yang berkaitan dengan penamaan suatu wilayah berkaitan dengan kajian sejarah, dan kebudayaan. Semiotika diungkapkan oleh 
Piliang (2012:343) adalah sebuah cabang keilmuan yang memiliki lingkup kajian sangat luas yang melipui hampir semua bidang kehidupan. Penjelasan yang ada di atas, peneliti merasa bahwa cukup penting untuk meneliti bagaimanakah toponimi penamaan desa yang berada di daerah Kecamatan Srono karena tidak banyak para pemuda pemudi yangmengetahui asal usul desa dan penelitian ini bisa sebagai reverensi nantinya untuk massa depan.Berangkat dari uraian di atas, maka terciptalah judul skipsi sebagai berikut. "Toponimi Desa seKecamatan Srono Kabupaten Banyuwangi”.

\section{Kajian Literatur dan pengembangan Hipotesis}

\section{Pengertian toponimi}

Toponimi suatu tempat merupakan sebagai hasil budaya, baik budaya secara historis dan simbolis. Menurut Liliweri(2014: 7-8) "budaya secara historis adalah bawaan sosial atau tradisi yang melewati generasi yang lalu ke generasi masa depan" dan budaya secara simbolis adalah"pendasaran makna yang ditetapkan bersama oleh masyarakat".Dalam hal ini, toponimi diartikan sebagai pemberian nama-nama tempat.Ilmu ini berkaitan erat dengan kajian
Linguistik, Antropologi, Geografi Sejarah dan Kebudayaan (Agustan, 2008).

Yulius (2004:2). Berpendapat "Toponimi adalah ilmu atau studi tentang nama-nama geografisToponim sendiri mempunyai arti "penamaan unsur-unsur geografis". Namanama pulau, gunung, sungai, bukit, kota, desa.

Toponim adalah nama dari objek tempat yang dibuat oleh manusia, dijelaskan lebih jauh oleh Hanks (2011:344).

Toponimi berpotensi untuk dijadikan sebuah sumber belajar dalam pendidikan geografi, namun dalam pelaksanaanya perlu menggunakan pendekatan antara geografi, sejarah, linguistik danfilsafat (Ayanovna, 2014:1060).

Penjelasan pemaparan diatas diambail dari jurnal "kajian nilai pada toponimi di wilayah kotacirebon sebagai potensi sumber belajar geografi”.

Adapun jurnal lain yang menjelaskan tentang toponimi salah satunya adalah,

(Rais, 2008: 53-54) Toponimi adalah pengetahuan yang mengkaji riwaat atau asalusul suatu tempat. Menurut KBB I(2012:1482 )toponimi merupakan cabang onmastika yang menyelidiki nama tempat.

Badan Riset Kelautan dan Perikanan (2003:3). memberikan pengertian toponimi 
sebagai penamaan unsur-unsur geografis yang dapat berupa nama-nama pulau, gunng, sungai, bukit kota, desa. Toponimi tidak dapat lepas dari aspek kajian linguistik, antropologi, geografi, sejarah, dan kebudayaan. Pemaparan diatas dimbil dari jurnal “ toponimi kabupaten lamongan

\section{(kajian antropologi linguistik)”.}

Kedua jurnal tersebut dapat di simpulkan bahwa toponimi yaitu sebuah nama yang diartikan sebagai penamaan tempat yang terkandung dalam sebuah unsur meliputi asal usul tempat tinggal di suatu tempat. Toponimi di desa sekecamatan srono mempunyai jumlah 10 desa yaitu : Bagorejo, Kebaman,Kepundungan, Parijatah kulon, Parijatah wetan, Rejoagung, Sukomaju, Sukonatar,Sumberari,Wonosobo.

Penelitian ini menggunakan pendekatan kualitatif. Penelitian kualitatif adalah tradisi tertentu dalam ilmu pengetahuan social yang secara fundamental bergantung pada pengamatan manusia dalam kawanannya sendiri dan berhubungan dengan orang - orang tersebut dalam bahasanya dan dalam peristilahannya. Penelitian kualitatif merupakan penelitian terhadap fenomena atau populasi tertentu yang diperoleh peneliti dari subjek yang berupa individu, organisasional atau perspektif yang lain.
Adapun tujuannya adalah untuk menjelaskan aspek yang relevan dengan fenomena yang diamati dan menjelaskan karakteristik fenomena atau masalah yang ada.

Penelitian kualitatif ini merupakan penelitian yang menelaah makna dari penamaan tempat (toponimi). Objek penelitian ini dibatasi wilayah administratif (Kecamatan Srono) namun untuk memperoleh data dari informan tidak ada batas administrasi.Penelitian ini mengkaji nilai-nilia toponimi di wilayah desa Kecamatan Srono. Toponimi yang ditelusuri dibatasi hanya diambil dari sembilan desa seKecamatan Srono.Penentuan toponimi mana saja yang diidentifikasi dalam penelitian ini dengan melihat keunikan sejarahnya nama yang merupakan asli nama tempat di desa Kecamatan Srono.

Metode penelitian terdiri dari dua kata yaitu metode dan penelitian. Metode berasal dari bahasa Yunani yaitu Methodos yang berarti cara atau jalan untuk mencapai penelitian yang berarti suatu cara untuk mencapai sesuatu dengan metode tertentu. Dengan cara hati-hati sistematik dan sempurna terhadap permasalahan yang sedang dihadapi. 
Husein Umar (2013:18) objek penelitian "Objek penelitian menjelaskan tentang apa dan atau siapa yang menjadi objek penelitian. Juga dimana dan kapan penelitian dilakukan.Bisa juga ditambahkan hal-hal lain jika dianggap perlu".

Selanjutnya menurut Supriati (2012:5) metode penelitian adalah tatacara bagaimana suatu penelitian dilaksanakan.

Penjelasaan ketigadi atas dapat disimpulkan bahwa metode penelitian adalah suatu cara atau prosedur untuk mendapatkan data terhadap suatu permasalahan dan tujuan serta kegunaan tertentu tanpa harus membuat perbandingan atau menghubungkan dengan objek lain. Dalam melaksanakan penelitian ini, untuk memperoleh data dan fakta yang diperlukan berkaitan dengan tujuan dengan judul yang diambil dalam tugas akhir ini penulis menggunakan metode penelitian deskriptif. Yaitu suatu cara penelitian dengan menggambarkan atau menguraikan secara jelas mengenai objek yang di teliti.

Menurut Supriati (2011:33). Penelitian deskriptif adalah untuk melukiskan secara sistematis fakta atau karakteristik populasi tertentu atau bidang tertentu, dalam hal ini bidang secara aktual dan cermat. Peneliti bertindak sebagai pengamat, ia hanya membuat kategori pelaku, mengamati gejala, dan mencatatnya dalam buku observasi.

Metode deskriptif kualitatif dalam penelitian ini dilakukan untuk mengetahui sejarah asal usul desa se- Kecamatan srono Kabupaten Banyuwangi.

\section{Kesimpulan}

Dalam penelitian ini diharapkan akan menemukan klasifikasi penamaan tempat desa di kecamatan srono sesuai dengan nama secara sejarah, pengharapan, alam dan buahbuahan.

\section{Daftar Pustaka}

Agustan.(2008). Toponimi, Bukan Hanya Tata Cara Penulisan Nama Unsur Geografis.Jurnal Inovasi Online.Vol. 11/XX/2008.

Arikunto, Suharsimi. 2010. Prosedur Penelitian Suatu Pendekatan Praktik. Jakarta :Rineka Cipta.

Ayanovna, N. L. (2014). The Role of Old Turkic Place Names in Teaching History.Procedia - Social and Behavioral Sciences $141 \quad$ (2014) 10541061.

Badan Riset Kelautan dan Perikanan (BRKP), 2003, Buku Panduan Survei Toponim Pulau-Pulau.Jakarta

Danang Suyono. 2013. Metode Dan Instrumen Penelitian (Untuk Ekonomi Dan Bisnis), Cetakan 1, Yogyakarta: CAPS (Center For Academic Publishing Service). 
Danang, Sunyoto. (2013). Metodologi Penelitian Akuntansi. Bandung: PT Refika Aditama Anggota Ikapi.

Departemen Pendidikan Nasional.2012. Kamus Besar Bahasa Indonesia Edisi IV.Jakarta: Gramedia

Hanks, R. R. (2011).Encyclopedia OfvGeography Terms, Themes, And Concepts. ABC-CLIO, LLC

Harbani, Pasolong.2013.Kepemimpinan Birokrasi. Bandung : CV.Alfabeta.

Harbani, Pasolong.2013.Kepemimpinan Birokrasi. Bandung : CV.Alfabeta.

Moleong, Lexy J. 2004. Metodologi Penelitian Kualitatif. Bandung: PT. Remaja Rosdakarya.

Liliweri, Alo. 2014. Sosiologi dan Komunikasi Organisasi. Jakarta: BumiAksara.

Piliang, Yasraf Amir. 2013. Semiotika dan hipersemiotika Gaya, Kode, dan Matinya Makna. Bandung: Matahari

Rais, Jacob, dkk. 2008. Toponimi Indonesia: Sejarah Budaya Bangsa yang Panjang dari Permukiman Manusia \& Tertib Administrasi. Jakarta: Pradnya Paramita.

Riduwan dan Akdon.(2010). Rumus dan Data dalam Analisis Data Statistika. Bandung: Alfabeta.

Riduwan.2010. Skala Pengukuran Variabelvariabel Penelitian. Bandung: Alfabeta.

Sugiyono. 2006. Metode Penelitian Kuantitatif, Kualitatif dan $\mathrm{R}$ D. Bandung: Alfabeta.

Umar,Husein.2013.Metode Penelitian Untuk Skripsi dan Tesis Bisnis. Jakarta: Rajawali Pers.

Yulius. 2004. Identifikasi Pulau Di Daerah Perbatasan Berdasarkan Kaidah Toponimi (Studi Kasus: Kabupaten Nunukan, Provinsi Kalimantan Timur).Pusat Riset Wilayah Laut Dan Sumberdaya Nonhayati. BRKP-DKP. 